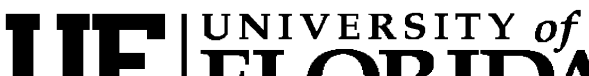 FLORIDA \\ IFAS Extension
}

\section{What Is and Isn't a Pesticide?1}

\author{
Frederick M. Fishel $^{2}$
}

The Federal Fungicide, Insecticide and Rodenticide Act (FIFRA) defines pesticides. Some substances might appear at first to be classified by FIFRA as pesticides, but this is not necessarily the case. This document will discuss FIFRA's criteria for determining what is and is not considered a pesticide.

\section{What makes a product a pesticide?}

One of the most important factors in defining a product as a pesticide is intent. As an early step in determining if a product is a pesticide, the U.S. EPA, in accordance with FIFRA, will consider whether the product is intended to be used as a pesticide. Products are generally considered to be pesticides if they are intended for preventing, destroying, repelling, or mitigating any pest or intended for use as a plant regulator, defoliant, or desiccant. The EPA determines intent by examining claims on the label, advertising, composition, use, and/or mode of action of the product as distributed or sold. Regulatory criteria in determining if a substance is a pesticide include:
- Claims. If a person distributing a product makes claims or implies that it is a pesticide by labeling or otherwise, then it is considered a pesticide. Such claims may be made through the product's advertising, collateral literature, or verbal statements.

- Composition. Products that have an active ingredient with no other significant commercial value other than pesticidal purposes have been historically considered pesticides. For example, if a manufacturer markets a product that lists dicamba as its active ingredient, but does not claim control of any broadleaf weeds, and the product label says to apply it to lawns at a certain rate and warns the user about injury due to over-application, would that product be classified as a pesticide? Most likely yes, because dicamba is a well known herbicide with no other significant commercial value.

- Knowledge that the substance will be used as a pesticide. If the manufacturer has knowledge that the substance will be used, or is intended to be used for a pesticidal purpose, the product is a pesticide and will require registration. This will

1. This document is PI-96, one of a series of the Pesticide Information Office, Florida Cooperative Extension Service, Institute of Food and Agricultural Sciences, University of Florida. Original publication date January 2006. Visit the EDIS Web Site at http://edis.ifas.ufl.edu.

2. Frederick M. Fishel, associate professor, Agronomy Department, and Director, Pesticide Information Office; Florida Cooperative Extension Service, Institute of Food and Agricultural Sciences, University of Florida, Gainesville, FL 32611.

The use of trade names in this publication is solely for the purpose of providing specific information. UF/IFAS does not guarantee or warranty the products named, and references to them in this publication does not signify our approval to the exclusion of other products of suitable composition. Use pesticides safely. Read and follow directions on the manufacturer's label.

The Institute of Food and Agricultural Sciences (IFAS) is an Equal Opportunity Institution authorized to provide research, educational information and other services only to individuals and institutions that function with non-discrimination with respect to race, creed, color, religion, age, disability, sex, sexual orientation, marital status, national origin, political opinions or affiliations. U.S. Department of Agriculture, Cooperative Extension Service, University of Florida, IFAS, Florida A. \& M. University Cooperative Extension Program, and Boards of County Commissioners Cooperating. Larry Arrington, Dean 
occur even if pesticidal claims are not made for the product.

\section{Pesticides exempted from registration}

Although some substances are considered pesticides, they are not regulated under FIFRA. This occurs because the pesticide has been determined to be adequately regulated by another Federal agency or has characteristics that make it unnecessary to be subject to FIFRA. Even though it may not be regulated by FIFRA, it may still fall under the jurisdiction of the Federal Food, Drug and Cosmetic Act (FFDCA) or Florida laws. For example, a certain pesticide might not be regulated by FIFRA, but it is regulated by FFDCA because it has tolerance requirements as a chemical residue in food.

Certain pesticides are not of a character requiring FIFRA regulation. Examples include treated articles, paints treated with antimicrobial pesticides that upon drying offer resistance to mildews, treated shower curtains with fungicides, pheromones and pheromone traps, and preservatives for biological specimens, such as embalming fluids. On the other hand, certain paints used in areas such as food processing plants and hospitals are generally not exempt from FIFRA regulation, because these are areas where a crucial consideration is prevention of molds and bacteria that would pose a health risk. During the 1990s, the EPA exempted 31 pesticidal active ingredients from FIFRA regulation. For an explanation and listing of these active ingredients, see UF/IFAS EDIS Document PI-55 Florida's Pesticidal Substances Exempt from the Federal Fungicide, Insecticide and Rodenticide Act (FIFRA-Section(25(b)) http://edis.ifas.ufl.edu/PI092.

\section{What is not a pesticide?}

Some substances are excluded from FIFRA registration under certain conditions or if they meet certain criteria.

- Liquid chemical sterilants. These are not considered pesticides if they meet all of the following:
1. If they are composed of liquid when sold or distributed. Pressurized gases or products in dry or semi-solid form are not excluded.

2. The product must bear a sterilant claim, or a sterilant plus lower level disinfection claim. For example, certain products containing chlorine for disinfection purposes around the home are not considered pesticides. Products that bear antimicrobial claims at a level less than sterilant are not excluded and are jointly regulated by EPA and FDA. Examples of these kinds of products include chlorine products used for sterilizing medical laboratory instruments and chlorine formulated as a pressurized gas.

3. The site where it will be used is considered. The product must be intended and labeled for use on "critical or semi-critical devices." A "critical device" is any device which is introduced directly into the human body, either into or in contact with the bloodstream or normally sterile areas of the body. A "semi-critical device" is any device that contacts intact mucous membranes but which does not ordinarily penetrate the blood barrier or otherwise enters normally sterile areas of the body. Liquid chemical sterilants that bear claims solely for use on non-critical medical devices are jointly regulated by EPA and FDA. Liquid chemical sterilants that bear claims solely for use on sites that are not medical devices, such as veterinary equipment, are not excluded and are regulated solely by the EPA.

- Nitrogen stabilizers. A nitrogen stabilizer is excluded from FIFRA regulation if it meets all of the following criteria:

1. The substance prevents or hinders the process of nitrification, denitrification, ammonia volatilization, or urease production through action affecting soil bacteria and is distributed and sold solely for those purposes and no other pesticidal purposes. 
2. The substance was in "commercial agronomic use" in the United States before January 1, 1992.

3. The substance was not registered under FIFRA before January 1, 1992.

4. Since January 1, 1992, the distributor or seller has made no claim that the product prevents or hinders the process of nitrification, denitrification, ammonia volatilization, or urease production.

- Products intended for use only for the control of fungi, bacteria, viruses, or other microorganisms in or on living man or animal, and labeled accordingly. For example, these products include athletes foot remedies, dandruff medications, aquarium additives for fish diseases, and dermal disinfectants. Insecticides used as tick and mosquito repellents on humans, pets and livestock have historically been considered as pesticides and require registration.

- Products intended for use only for control of internal invertebrate parasites or nematodes in living man or animals, and labeled accordingly.

- Products intended only to aid in the growth of desirable plants. FIFRA distinguishes between plant nutrients, which may be exempt, and plant regulators, which require registration. Plant growth regulators are generally claimed to cause such actions as increased blossom set, stimulation of root growth, prevention of sucker growth, delayed onset of sprouting of harvested root crops, and abscission stimulation for fruit crops. EPA considers such substances to go beyond what would be expected from simple nutrition. Products that aid in the growth of desirable plants can include:

- Plant or leaf coatings designed to protect against frost or to retard water loss through transpiration.

- Products containing simple sugars sold as vase water additives for cut flowers.

- Food washing products that do not claim to remove bacteria such as e-coli or salmonella.
- Fertilizer products not containing a pesticide, such as sphagnum moss used as plant growth media to retard damping-off.

- Plant inoculant products consisting of microorganisms applied to the plant or soil for the purpose of enhancing the availability or uptake of plant nutrients through the root system.

- Soil amendments, such as vermiculite, sand or lime, used to improve soil characteristics favorable for plant growth.

- Plant nutrient products consisting of one or more macronutrients or micronutrient trace elements necessary for normal growth of plants and in a form readily useable by plants.

- Antimicrobial products used solely in processed foods or feeds, in beverages, or in pharmaceuticals.

- Deodorizers, bleaches, and cleaning agents. In some cases, these types of substances would fall under FIFRAs regulation. For example, a bleach containing $5.25 \%$ sodium hypochlorite would likely require registration if the label claims to kill bacteria at certain doses. An identical bleach sold as a different product would not likely need to be registered if the labeling only claims to whiten, bleach or clean laundry, and does not contain an explicit or implicit antimicrobial claim.

- Products not containing toxicants intended only to attract pests for survey or detection purposes, and labeled accordingly. Examples are insect pheromone products used to place in traps for monitoring insect populations.

- Products that are intended to exclude pests only by providing a physical barrier against pest access, and which contain no toxicants. An example is mulch that claims suppression of weed growth. 


\section{Are devices considered to be pesticides?}

FIFRA defines a device as "any instrument or contrivance (other than a firearm) which is intended for trapping, destroying, repelling, or mitigating any pest or any other form of plant or animal life (other than man and other than bacteria, virus, or other microorganism on or in living man or other living animals); but not including equipment used for the application of pesticides when sold separately therefrom." Devices do not have to be registered under FIFRA; however, they are subject to some FIFRA's provisions, including labeling requirements and establishment numbers identifying the location where the device was produced.

\section{Additional Information}

Fishel, F.M. 2005. Florida's pesticidal substances exempt from the Federal Fungicide, Insecticide and Rodenticide Act (FIFRA-Section(25(b)). UF/IFAS EDIS Document PI-55. http://edis.ifas.ufl.edu/PI092

Fishel, F.M. 2005. How are pesticides classified? UF/IFAS EDIS Document PI-46. http://edis.ifas.ufl.edu/PI083. 